\title{
Bernadeta Wilk
}

\section{Sławne pogrzeby w XIX-wiecznym Krakowie}

W XIX wieku losy Krakowa były bardzo zmienne. Początkowo pod zaborem Austrii, w 1815 roku został ustanowiony Rzeczpospolita Krakowska. Od 1846 roku znów dostał się pod panowanie austriackie, które po okresie ucisku, począwszy od lat sześćdziesiątych dało Galicji autonomię. W XIX wieku Kraków cieszył się pewną swobodą. Szczególnie w okresie autonomii galicyjskiej (1866-1914) Kraków stał się najważniejszym ośrodkiem życia społeczno-politycznego Galicji oraz ogólnopolskim centrum życia narodowego i kulturalnego. Kraków, miasto koronacyjne i nekropolia królewska, stał się centrum polskości, zyskując w XIX wieku miano duchowej stolicy Polski.

Wyjątkowe położenie Krakowa w porównaniu z ogarniętymi represjami ziemiami polskimi zaboru rosyjskiego i gnębionymi germanizacją ziemiami zaboru pruskiego sprawiło, że ta dawna stolica Polski zaczęła spełniać funkcję ponadzaborowa, zdobywając pierwsze miejsce $w$ życiu zgnębionego narodu ${ }^{2}$. Tutaj $\mathrm{z}$ dużą swobodą rozwijało się życie narodowe i można było krzewić narodowego ducha polskiego. Zdawano sobie bowiem sprawę, że jest to miasto idei, pamiątek i żywych tradycji, z których pokolenia mogą czerpać „żywą wodę”3. O tej szczególnej roli Krakowa w tym czasie zadecydowała nie tylko sama autonomia, ale i symbolika tego miasta - dawnej stolicy państwa polskiego. Jako „szacowna skarbnica na-

\footnotetext{
"Artykul ten jest poszerzoną wersją referatu, wygloszonego 8 XI 2005 r. w Towarzystwie Miłośników Historii i Zabytków Krakowa.

'F. Zi e j k a, ,Tu wszystko jest Polską...”. (O roli Krakowa w życiu duchowym Polaków w wieku XIX), „Rocznik Krakowski” 62:1996, s. 31-35; K. G r o d z i s k a - O ż ó g, Ze studiów nad rolq Krakowa w epoce porozbiorowej, „Rocznik Biblioteki Polskiej Akademii Nauk w Krakowie” 31:1986, s. 151; B. P r u s, Kartki z podróży, t. 1, Warszawa 1950, s. 155; W. M. B a r t e 1, Czy Kraków na przetomie XIX iXX wieku byt "polskim Rzymem", [w:] Kraków na pızelomie XIX $i$ XX wieku. Materiaby sesji nankowej z okazji dni Krakowa w 1981 roku, pod. red. J. M. M a ł e c k i e g o, Kraków 1983, s. 75.

${ }^{2}$ M. R o ż e k, Genius loci Krakowa, „Alma Mater” nr 19:2000, s. 30-32.

${ }^{3}$ Te n ż e , Rola Krakowa wświadomości narodowej, „Życie Szkoły Wyższej” 32:1984, nr 1, s. 54.
} 
rodowych pamiątek i złota księga polskiej historii”4, Kraków był „Polski sercem, a narodowości ogniskiem świętym, przedstawcą ojczystych dziejów" i siedliskiem polskiego ducha narodowego. $\mathrm{Z}$ tego podwawelskiego grodu promieniowała na cały naród przeszłość Polski, a kultywowane tu stare tradycje i obyczaje podtrzymywały ducha narodowego Polaków w ciężkich chwilach niewoli, rozbudzając nadzieję i świadomość narodową ${ }^{6}$.

Tragedia rozbiorów spowodowała w społeczeństwie polskim wzrost nastrojów patriotycznych i zwrot ku wartościom rodzimej tradycji. Kraków posiadał atut w postaci duchowego i materialnego dziedzictwa przeszłości, nagromadzonego przez stulecia, a już pierwsza połowa XIX wieku ugruntowała romantyczny mit Krakowa, jako świętego miejsca Polaków, będącego źródłem pokrzepienia i nadziei ${ }^{7}$. W sferze symboliki patriotycznej, stanowiącej ważny czynnik krzewienia i umacniania świadomości narodowej, doniosłą rolę zaczęły odgrywać organizowane w Krakowie uroczystości patriotyczno-religijne ${ }^{8}$. Dla krzewienia idei patriotycznych Kraków sięgnął do zasobów historii. Ustalił się pewnego rodzaju ,archeologiczny patriotyzm", polegający na uroczystym obchodzeniu rocznic narodowych i celebrowaniu pogrzebów zasłużonych Polaków. W XIX wieku Kraków stał się scenq narodowego spektaklu ${ }^{10}$, na której organizowane były pogrzeby wybitnych Polaków. Pod koniec XIX wieku twierdzono nawet, że „największym przemysłem ówczesnego Krakowa były obchody rocznicowe i pogrzeby wielkich Polaków"ll.

W okresie niewoli narodowej, groby monarsze na Wawelu, uświadamiając potęgę Rzeczypospolitej zaczęły mieć znaczenie patriotyczne i wychowawcze. Jak ewangeliczne lapides vivi (żywe kamienie) uczyły Polaków dziejów ojczystych. Kult i pietyzm narodowy, jakim społeczeństwo polskie obdarzało groby królewskie, zdając sobie sprawę z "milczącej mowy kamieni”"12 sprawiły, że kiedy nie było już monarchów, postanowił naród składać w tym narodowym sanktuarium dziejowym, w podziemiach katedry na Wawelu, doczesne szczątki bohaterów naro-

\footnotetext{
${ }^{4} \mathrm{~J} . \mathrm{D} u$ ż y k, „Polskie Ateny”, [w:] Kraków stary i nowy. Dzieje kultury, pod. red. ]. B i e n i a r z ó w n y, Kraków 1968, s. 343.

${ }^{5}$ J. K r e m e r, Kraków wobec Polski i Sukiennice jego oraz stowo o Bramie Floriańskiej, Kraków 1870, s. 25; M. B o row i j ska-B i rken ma je rowa, Serce Polski. Zabytki i świadomość narodowa, Kraków 1991, s. 113.

${ }^{6}$ B. W i l k , Autonomiczny Kraków skarbnica narodowych pamiatek, „Folia Historica Cracoviensia" 10: 2004, s. 419-430.

${ }^{7}$ J. B i e niarzówn a, J. M. M ał e c k i, Dzieje Krakowa, t. 3. Kraków w latach 1796-1918, Kraków 1979, s. 55-59.

${ }^{8} \mathrm{~B} . \mathrm{W}$ i I k, Uroczystości patriotyczno-religijne $w$ Krakowie w okresie autonomii galicyjskiej 1860 -1914, (w druku).

${ }^{9}$ J. O s t r ow s k i, Kraków, Kraków 1989, s. 91.

${ }^{10}$ R. K a n t or , Kalejdoskop krakowski. Gawędy o Krakowie, krakowianach $i$ ich zwyczajach, Toruń 1996, s. 17-18; tenże, Kraków - wielka scena narodowego teairu, [w:] Klejnoty i sekrety Krakowa. Teksty' z antropologii miasta, pod red. R. G o d u I i, Krakow 1994, s. 47-57.

${ }^{11} \mathrm{~K}$. K a r o I c za k, Wtaściciele domów w Krakowie na przetomie XIX i XX wieku. Z badań nad dziejami Krakowa, Kraków 1987, s. 15.

${ }^{12}$ M. R o ż e k, Wawelska nekropolia, Kraków 1984, s. 22.
} 
dowych i wieszczów ${ }^{13}$, kontynuując w ten sposób historyczną tradycję. Zainicjowane w pierwszych latach XIX wieku uroczystymi pogrzebami bohaterów narodowych, odżyły na nowo w czasach autonomii galicyjskiej na niespotykaną dotąd skalę.

Utworzone w 1815 roku Wolne Miasto Kraków, zwane Rzeczpospolita Krakowską stało się świadkiem dwóch manifestacji narodowych. W 1817 i 1818 roku mury wawelskie przyjęly szczątki dwóch, wielkich bohaterów narodowych. W 1817 roku (22-23 lipca) odbyły się w Krakowie uroczystości pogrzebowe księcia Józefa Poniatowskiego, a rok później 22-23 czerwca złożono w krypcie św. Leonarda trumnę ze zwłokami Naczelnika Tadeusza Kościuszki ${ }^{14}$. Wedle naocznego świadka tych pamiętnych dni „pogrzeby te na umysły oddziałały, były one jakby przeglądem ostatnich dziejów Polski. Rozrzewnieni starce wracali do domu jakby z Ziemi Świętej, czyniąc ofiary z uczuć, na jakie tylko zdobyć się mogli, każdy przekazywał swemu następcy obowiązki z uczuć tych i ślubów płynące. [...] Serca nasze biły mocno na opowiadania wojowników, którzy pod nimi służyli. Czyniliśmy im jedne za drugimi zapytania, aż pojęliśmy, że oni wiedzą jedynie o przeszłości, a przyszłość na nas spoczywa. Z tego pogrzebu duch Polski, jakby zawołał na nas: Jeszcze Polska nie zginęła" ${ }^{15}$. Te dwa głośne pogrzeby narodowe oraz pogrzeb Artura Potockiego w 1832 roku $^{16}$ - postaci lokalnej, jednak powszechnie nie tylko w Krakowie wysoko cenionej za wojenne zasługi i dobroczynność - dały na wiele lat pewien wzór narodowej uroczystości funeralnej urządzanej w Krakowie w XIX stuleciu. Z prastarej katedry, która przed wiekami przyjmowała prochy królów, a teraz wielkich mężów, zaczęto tworzyć Narodowy Panteon. Jego potrzebę rozumiano szczególnie w XIX wieku, kiedy grób integrował Polaków, przypominając chlubne dzieje narodu polskiego i pozwalając wierzyć w przyszłe odrodzenie Polski.

Serię wielkich pogrzebów na Wawelu w dobie autonomicznej zainaugurował, niezwykle symbolicznie, powtórny pogrzeb króla Kazimierza Wielkiego, zmarłego 5 listopada 1370 roku $^{17}$. Dnia 14 czerwca 1869 roku, w czasie robót konserwatorskich przeprowadzanych w wawelskiej katedrze odnaleziono przypadkiem zwłoki Kazimierz Wielkiego, o których dotąd nie wiedziano, gdzie były pochowane. Wieść o odkryciu grobu króla chtopków w katedrze wawelskiej rozeszła się po całej Polsce, wywierając wielkie wrażenie i podnosząc na duchu przygnębionych

${ }^{13}$ M. R oż e k, A. B u j a k, Nekropolie królów i ksiq̨żąt polskich, Warszawa 1988, s. 37; Idem, Wawel i Skatka-panteony polskie, Wrocław 1995, s. 5-6, 10.

${ }^{14} \mathrm{~J} . \mathrm{B}$ u s z k o, Uroczystości patriotyczne na Wawelu w latach Rzeczypospolitej Krakowskiej $i$ w dobie autonomii galicyjskiej, „Annales Universitatis Mariae Curie-Skłodowska” sectio F: Historia, vol. 51:1996, s. 32-35; S. Windakiewicz, Dzieje Wawelu, Kraków 1925, s. 207-210.

${ }^{15} \mathrm{~K}$. G i r ll e r, Opowiadania, t. 1, Pamiętniki z lat $1803-1831$, wyd. Z. J a b lo ńs k i, J. S t a s z e 1, Kraków 1971, s. 181.

${ }^{16}$ J. Louis Wawel, Urywki z dziejów i życia mieszkańców Krakowa, Kraków 1977, s. 211-213; A. Polarczykowa, Artur Porocki i jego pałac „Pod Baranami” w Krakowie, Kraków 1995, s. $254-262$. (Biblioteka Krakowska nr 134)

${ }^{17}$ R. S k o w r o n, Kalendarium dziejów Wawelu do roku 1905, Kraków 1990, s. 41-43. 
upadkiem powstania styczniowego Polaków ${ }^{18}$. „Wrażenie, jakie wiadomość ta w całym kraju wywołała - pisał Józef Ignacy Kraszewski - opisać, wypowiedzieć się nie daje... Poruszyło ono serca wszystkich, jednogłośnie zrodziła się myśl nowego pogrzebu i złożenia relikwii tych w odpowiedniej im, królewskiej trumnie. Jak iskrą elektryczną poruszyli się wszyscy, domagając się, aby ofiarą, przytomnościa, uczuciem uczestniczyć w obrzędzie narodowym... Nie pamiętamy od dawna takiego zapału, rozrzewnienia, tak powszechnego wzruszenia wszystkiego, co się polskim miało... To zjawienie się wśród żywych wielkiego króla prawodawcy, reformatora, na grobie Polski rozszarpanej, rozsypanego w proch, z ostatnią polską koroną i jedynym berłem naszym... miało w sobie coś mistycznie działającego, jakby wywołującego wspomnieniem przeszłości wiarę w przyszłość"19.

Na uroczystości kazimierzowskie przybyli do Krakowa członkowie cechów i stowarzyszeń rzemieślniczych, delegaci izb przemysłowo-handlowych i adwokackich, reprezentanci gmin miejskich i rad powiatowych, deputacje włościan i Żydów, profesorowie Uniwersytetu Jagiellońskiego i Lwowskiego, przedstawiciele towarzystw naukowych i rolniczych oraz posłowie na Sejm Krajowy i posłowie wielkopolscy. Z zaboru rosyjskiego nie było nikogo, gdyż udział w pogrzebie groził prześladowaniem. Wszyscy należący do orszaku pogrzebowego ubrani byli w stroje narodowe lub żałobne. Obchód rozpoczął się uroczystym pochodem z kościoła Najświętszej Maryi Panny na Wawel. Po Mszy św. o godzinie 8, przy dźwiękach dzwonu Zygmunta wyruszył przy pięknej, słonecznej pogodzie, żałobny, pozbawiony trumny kondukt. Sklepy w całym mieście były pozamykane, a z wielu okien kamienic, zwłaszcza na ulicach, którymi przechodził orszak, powiewały czarne i narodowe choragwie. Wszystkie okna kamienic w Rynku Głównym, na ul. Grodzkiej, wzdłuż Podzamcza, na Zamku, a nawet dachy i bramy były oblężone przez publiczność, przypatrująca się pochodowi. Pomimo kilku tysięcy widzów, wszędzie panowała wielka cisza. Brak muzyki, śpiewów, wojska i policji sprawiły, że pochód miał charakter czysto polski i zupełnie narodowy. Powoli i dostojnie, wśród bicia dzwonów krakowskich kościołów, szedł pochód na Wawel. Tu w katedralnym prezbiterium ustawiono olbrzymi katafalk, wykonany według projektu Jana Matejki „sięgający prawie, aż do połowy wysokości świątyni, obity ciemnoszkarłatnym aksamitem, lamowany złotym galonem i przyozdobiony od góry festonem ze złotych frędzli. Nad katafalkiem wznosił się baldachim z aksamitu tegoż

\footnotetext{
${ }^{18}$ Archiwum Krakowskiej Kapituły Katedralnej (dalej: AKKK), Acta actorum illustrissini capituli ecclesiae cathedralis Cracoviensis, t. 33 (1861-1874), s. 493, 498; J. B u s z k o, Uroczystości kazimierzowskie na Wawelu w roku 1869, Kraków 1970, s. 10-12, 17-18, 72-74, 108-11; Archiwum Uniwersytetu Jagiellońskiego w Krakowie (dalej: AUJ), S II 964, Protokót opróżnienia tumby grobowej z dnia 21 VI 1869 ; W. L. A n c z y c, Pamiatka odkrycia zwłok Kazimierza Wielkiego, z dodaniem wiadomości o życiu tego króla, spisanych dla ludu przez Kazimierza Góralczyka (W. L. Anczyca) oraz chronologii wszystkich czynów i wypadków za jego panowania. Z 7 obrazkami przedstawiajacymi dwa wizerunki Kazimierza Wielkiego, oraz znalezionych w grobowcu na Wawelu oznak królewskich, wziętych z forografii W. Rzewuskiego, Kraków 1869, s. 15-18; AUJ, S II 964, Program uroczystego pochowania zwłok króla Kazimierza Wielkiego.

${ }^{19} \mathrm{~B}$. B o l es 1 a w i t a [Kraszewski Józef Ignacy], Z roku 1869 rachınki, Poznań 1870, s. 300-301.
} 
samego koloru, w kształcie korony, od której spływały łukami cztery szerokie aksamitne szarfy. Przed katafalkiem stał olbrzymi biust Kazimierza Wielkiego, przy jego narożnikach ustawiono cztery sztandary z amarantowej materii jedwabnej z Orłem i Pogonią oraz symbole zbroi rycerskich, boki natomiast zdobiły malowane tarcze, po dwie z każdej strony, wyobrażające herby: Krakowa, Lwowa, Uniwersytetu Krakowskiego i Kapituły Krakowskiej"20. Kiedy wszystkie delegacje weszły do katedry, duchowieństwo pod przewodnictwem kanonika hr. Scipio del Campo rozpoczęło obrzędy. Żałobny orszak wyszedł bocznymi drzwiami od kaplicy Zygmuntowskiej, okrążył katedrę, powrócił do niej głównymi drzwiami, a następnie obszedłszy całe wnętrze nawami bocznymi i ambitem, udał się środkiem nawy głównej do prezbiterium. Na czele konduktu szło duchowieństwo zakonne ze wszystkich klasztorów krakowskich, duchowieństwo świeckie z całego kraju oraz członkowie kapituły krakowskiej. Trumnę królewską nieśli dwaj chłopi z Łobzowa (była to wieś królewska, a Kazimierz Wielki przebywał tam nieraz w swym dworze), dwaj studenci, wiceprezydent miasta Feliks Szlachtowski. Postępujący za trumną marszałek krajowy Leon Sapieha niósł na aksamitnej poduszce kopie insygniów królewskich, odnalezionych w grobie. Dalej szli delegaci powiatów, reprezentanci różnych stowarzyszeń, władze Wszechnicy Jagiellońskiej i grono obywateli $w$ żałobnych strojach polskich. Po uroczystej sumie celebrowanej przez administratora diecezji krakowskiej bp. Antoniego Gałeckiego, odśpiewaniu egzekwii, zdjęto trumnę z katafalku, a orszak pogrzebowy wyszedł z głównej nawy kościoła i zatrzymał się przed rozebranym pomnikiem Kazimierza Wielkiego. Kondukt w asyście ponad stu księży prowadził bp Antoni Gałecki, bp tarnowski Józef Pukalski i infułat tarnowski Franciszek Szlosarczyk. Po odśpiewaniu Salve Regina złożono trumnę w starym sarkofagu, który następnie zamurowano.

Powtórny pogrzeb ostatniego Piasta przypomniał Polakom o roli narodowych katakumb, których przez wieki strzegły mury wawelskiej katedry. „Są bowiem takie chwile w życiu narodu, że potrzebne są dodatkowe czynniki, ożywiające zdrętwiały organizm" ${ }^{21}$ i takim wydarzeniem było właśnie odkrycie monarszych szczątków. Naród bowiem, na który spada nieszczęście wierzy w cuda, a w zdarzeniach niezwykłych szuka zapowiedzi lepszej przyszłości. Powszechnie sądzono, że tak jak za Przemysława odnalezienie korony Bolesława Chrobrego oznaczało koniec klęsk narodowych, rozpoczynając nową epokę, tak samo znalezienie szczątków Kazimierz Wielkiego i jego insygniów miało zwiastować przełom w życiu narodu polskiego ${ }^{22}$. Najlepszym tego dowodem jest rapsod Kazimierz Wielki pióra Stanisława Wyspiańskiego ${ }^{23}$, który po kilkudziesięciu latach po tych wydarzeniach na podstawie domowej tradycji, odtworzył nastrój tego osobliwego pogrzebu:

\footnotetext{
${ }^{20} \mathrm{~J}$. B u s z k o, Uroczysfości kazimierzowskie na Wawelu..., s. 80-81.

${ }^{21}$ J. D u ż y k, Pamięć o wielkim władcy, „Życie Literackie” 21:1971, nr 5, s. 7.

22 [Rycharski Lucjan Tomasz], Pamiqutka odkrycia i pogrzebania zwlok Kazimierza Wielkiego, Kraków 1869, s. 6-7.

${ }^{23}$ K. W y k a, Sześćset $i$ sto lat temu, „Miesięcznik Literacki” 6:1971, nr 4, s. 32-34.
} 


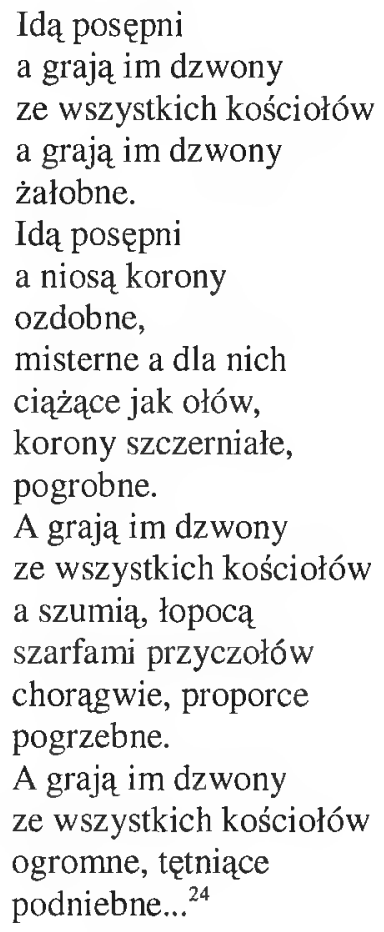

Druga, wielką uroczystością pogrzebową o wydźwięku głęboko patriotycznym było sprowadzenie zwłok Adama Mickiewicza w 1890 roku, zmarłego w 1855 roku w Stambule. W XIX wieku literatura, a szczególnie poezja była tą dziedziną życia, w której właściwe miejsce znajdowała myśl narodowa. Naród pozbawiony własnego państwa, wodzów postanowił uczcić duchowego przywódcę, który w swoich dziełach mówił o powstaniu niepodległej Polski. Jedynym miejscem, w którym można było z właściwą czcią złożyć prochy wieszcza była królewska katedra na Wawelu ${ }^{25}$. Po uzyskaniu odpowiedniego zezwolenia i zebraniu potrzebnych funduszy, 20 czerwca 1890 roku delegacja krajowa wyjechała do Paryża w celu dokonania ekshumacji i przewiezienia prochów Adama Mickiewicza na ostateczny spoczynek w grobach katedralnych na Wawelu. Dnia 3 lipca w późnych godzinach wieczornych zwłoki wieszcza dotarły pociągiem z Montmorency pod

${ }^{24}$ S. W y s p i a ń s k i, Dzieła zebrane, t. 11, Kraków 1961, s. 37-38.

${ }^{25}$ [Litwin], Zanieśmy prochy Mickiewicza na Wawel, „Kraj” 1:1869, nr 44, s. 1; AKKK, Acta actorum..., t. 34 (1875-1898), s. 293-295; M. Ś w i ą te c k a, Sprowadzenie zwtok Adama Mickiewicza do kraju, [w:] Kraków Mickiewiczowi, pod red. D. Rederowej, Kraków 1956, s. 27-38; [Władysław Prokesch], Pamiqutka zlożenia zwtok Adama Mickiewicza w katedrze na Wawelu w Krakowie 4 lipca 1890 r., Kraków 1890 , s. $73-82$. 
Paryżem do Krakowa ${ }^{26}$. Trumnę tymczasowo złożono w składach zbożowych przy ul. Warszawskiej. Na uroczysty moment pogrzebu Kraków przybrał dostojny i odświętny wygląd. W całym mieście panowała gorączka przygotowań27. Wzdłuż trasy pochodu powiewały zawieszone na słupach choragiewki i flagi o barwach narodowych. Słupy połączono girlandami z zieleni, a w kilku miejscach ustawiono ozdobne pylony, na których podczas pochodu płonęło purpurowe światło. W Rynku, naprzeciw ul. Siennej wzniesiono obelisk ku czci poety, przyozdobiony symboliczna lirą i medalionem z podobizną Wieszcza. Domy prywatne i ulice przylegające do drogi pochodu przybrano zielenia, kwiatami, dywanami i sztandarami, a wszystkie sklepy pozamykano. Naprzeciw domu, w którym mieściły się biura krajowych składów zbożowych przy ul. Warszawskiej umieszczono duży obraz Matki Boskiej Ostrobramskiej. W piątek, 4 lipca tłumy krakowian i przyjezdnych gości zaczęły wypełniać ulice i place miasta. Jak pisał świadek tamtych wydarzeń w ogromnym orszaku „mieniły się tysiączne wspaniałe barwy: świt włościańskich, krakowskich, ruskich, góralskich, huculskich. Obok świt włościańskich i sukman zmieszane razem z nimi i wśród nich stroje narodowe szlachty, charakterystyczne kapoty mieszczan. Ponad tym strzelają czaple kity, mienią się brylantowe ich zapinki, błyszcza kaski strażaków. Na czele duchowieństwa w imponujacej liczbie przeszło 500 kapłanów, profesorowie Uniwersytetu Jagiellońskiego i Lwowskiego w togach i z insygniami, posłowie sejmowi. Słowem, kiedy się powiodło okiem po tych tysiącach widziało się jasno i dobitnie, że cały naród, wszystkie jego stany, stawiły się na uroczystą chwilę"28. O godzinie 8 , kiedy przybyła najbliższa rodzina Mickiewicza, duchowieństwo i dygnitarze państwowi, przy wtórze dzwonów z kościoła św. Floriana, rozpoczęły się uroczystości pogrzebowe ${ }^{29}$. Po modlitwach, które odprawił abp lwowski obrządku ormiańskiego ks. Izaak Issakowicz, wyniesiono trumnę i ustawiono na karawanie. Uczestnicy ceremonii opisywali karawan jako wielką piramidę obitą ciemnoczerwonym pluszem, nad którą wznosił się wysoki baldachim. Cały pojazd, ozdobiony polnymi kwiatami i ciągnięty przez sześć karych koni budził powszechny podziw widzów. Marszałek krajowy hr. Jan Tarnowski przyjął zwłoki Wieszcza, po czym różnobarwny korowód ruszył z miejsca. Na czele pochodu szła orkiestra lwowskiej Harmonii, a za nią oddział ochotniczej straży pożarnej. Poprzedzał on deputacje włościan niosących czterdzieści cztery wieńce ze wstęgami, na których były napisy i cytaty z utworów Mickiewicza. Pierwszy wieniec przedstawiał godło ludowe (sierp z gwiazda postępu), a następne tworzyły ra-

${ }^{26}$ AUJ, S II 964, Akt ekshumacji zwtok Adama Mickiewicza, Montmorency 27 VI 1890; Na Wawel, [w:] Na odstonięcie pomnika Mickiewicza w Krakowie, Lwów 1898, s. 10; Mowy wygłoszone w dn. 28 VI 1890 z powodu przeniesienia zwlok Adama Mickiewicza z Montmorency na Wawel, Paryż 1890, s. 18-19.

${ }^{27}$ A. W od z i c k i, Program uroczystości złożenia zwłok Adama Mickiewicza w' podziemiu kościoła katedralnego na Wawelu w Krakowie, [w:] [Władysław Prokesch], Pamiatka złożenia..., op. cit., s. 82-87.

${ }^{28}$ Zlożenie zwlok Adama Mickiewicza na Wawelu dnia 4-go lipca 1890 roku. Ksiqżka pamiqtkowa, Kraków 1890 , s. 67.

2" Ztożenie zwlok Mickiewicza na Wawelu, "Czas" 43:1890, nr 152, s. 1-4; Uroczystość zlożenia zwlok Adana Mickiewicza w grobach królewskich na Wawelu, „Kurier Polski” 2:1890, nr 184, s. 1-2. 
zem napis: ADAMOWI MICKIEWCZOWI LUD WSZYSTKICH ZIEM POLSKI. Pierwsze „A" uwito z kłosów pól, gałązek borów litewskich i modrzewia sadzonego przez króla Jana Sobieskiego, drugie „A” z szarotek i kosodrzewiny zakopiańskiej, „U” z kłosów Królestwa Polskiego, „S” z gałązek zebranych w pruskim i austriackim Śląsku, „W” z kłosów i zieleni Wielkopolski ${ }^{30}$. W ten sposób lud wszystkich ziem Polski złożył hołd swojemu Królowi-Ducha. W pochodzie szli przedstawiciele rad miejskich, reprezentanci wyższych uczelni i duchowieństwo. Na pogrzeb Adama Mickiewicza licznie przybyli mieszkańcy Królestwa Polskiego, Litwy, Ukrainy, Wołynia, Podola, Poznańskiego, Śląska, Warmii oraz Polacy z emigracji. Swoich delegatów przysłali także Czesi, Serbowie i Bułgarzy. Za delegacjami posuwał się karawan, a za nim postępowała rodzina poety, Wydział Krajowy oraz posłowie do rady państwa i sejmu ${ }^{31}$. Trasa pochodu prowadziła przez ul. Warszawską, Basztową i Sławkowską do Rynku Głównego. Kondukt pogrzebowy szedł dostojnie i powoli „wśród ulewy kwiatów, rzucanych z okien, balkonów, chodników"32. Przed kościołem Najświętszej Maryi Panny, połączone chóry odśpiewały dwie pieśni, po czym pochód wszedł w ul. Grodzką. Od kościoła Mariackiego na Wawel prowadził kondukt metropolita lwowski abp Seweryn Morawski. Trwający trzy godziny pochód, dotarł o godzinie 11 do stóp Wawelu, gdzie „ozwały się na powitanie nowego mieszkańca królewskich sklepień, poważne i uroczyste dźwięki dzwonu Zygmunta"33. Po przemówieniach trumnę wniesiono do katedry i postawiono na katafalku. Mszę św. żałobną celebrował kard. Albin Dunajewski, a homilię wygłosił profesor Uniwersytetu Jagiellońskiego ks. Władysław Chotkowski. Kaznodzieja podkreślił uszanowanie przez naród zasług Króla-Ducha, czego najlepszym wyrazem było uhonorowanie poety królewskim pogrzebem i złożenie jego prochów w polskiej nekropoli na Wawelu, będącej „Sichem naszego narodu" ${ }^{34}$. Około godziny 3 po południu, uroczystość złożenia prochów Adama Mickiewicza na Wawelu zakończyła się. Kardynał Dunajewski i abp Issakowicz wraz z duchowieństwem odśpiewali przed katafalkiem Castrum Doloris, po czym przy dźwiękach Salve Regina zaniesiono trumnę wieszcza do krypty przed kaplicą Lipskich i złożono w sarkofagu na piasku $\mathrm{z}$ dna Niemna i ziemi $\mathrm{z}$ Nowogródka ${ }^{35}$. Na łuku sklepienia umieszczono tarczę z herbami Polski, Litwy i Rusi, a nad sarkofagiem powieszono lampę z umbrą w kształcie orła. W niszy ściennej wmurowano mensę ołtarzową, powyżej której umieszczono mozaikowy wizerunek Madonny

\footnotetext{
${ }^{30}$ Ztożenie zwtok Adama Mickiewicza na Wawelu..., s. 51.

${ }^{31}$ A. R e c z y ń s k a, „,..tak nas powrócisz cudem na Ojczyzny tono...". Krakowski pogrzeb Adama Mickienicza, „Kraków. Magazyn Kulturalny” nr 2/4, 1987, s. 11.

${ }^{32}$ M. S w i a t e ck a, Sprowadzenie zwtok..., op. cit., s. 56.

${ }^{33} \mathrm{Na}$ Wawel..., s. 14.

${ }^{34}$ W. Chotk ow ski, Mowa przy sprowadzeniu zwtok śp. Adama Mickiewicza powiedziana w czasie nabożeństwa w katedrze na Wawelu dnia 4 lipca 1890, Kraków 1890, s. 6.

${ }^{35}$ AKKK, Acta actorum..., t. 34 (1875-1898), s. 429; M. R o ż e k, Groby królewskie w Krakowie, Kraków 1977, s. 164-166.
} 
Ostrobramskiej ${ }^{36}$. Nie był to zwykły pogrzeb, ale „uroczyste zwłok przeniesienie i podniesienie podobne temu, jakie obchodzi Kościół Boży, kiedy relikwie świętych z jednego miejsca na drugie przenosi" ${ }^{37}$. Ten podniosły akt złożenia zwłok Wieszcza w panteonie narodowych pamiątek na Wawelu miał charakter spokojnej manifestacji ducha i uczucia narodowego. Hołd u trumny wielkiego poety złożyli „przedstawiciele wszystkich krajów i ziem polskich, wszystkich stanów i warstw społecznych. Od płótnianki włościanina, burki góralskiej, kapoty mieszczańskiej począwszy, aż do bogatych strojów szlachty i magnatów do podbijanych futrem delij, lśniących od jedwabiu i litych materii kontuszy i żupanów, stanęli wszyscy oddać hołd temu co ukochał naród cały, cierpiał za miliony i wieszczył im świetlaną przyszłość" ${ }^{38}$. W ten sposób zarówno dla społeczeństwa polskiego, jak i całej Europy, dzień pogrzebu Mickiewicza w Krakowie był nie tylko dniem ostatniego triumfu wieszcza, ale także wielkim dniem triumfu Polaków i sprawy polskiej ${ }^{39}$.

Drugim, obok Wawelu miejscem urządzania sławnych pogrzebów w XIX-wiecznym Krakowie była Skałka - miejsce męczeńskiej śmierci biskupa krakowskiego Stanisława. Kult św. Stanisława, królewskie pielgrzymki na Skałkę oraz legenda o życiu i tragicznej śmierci biskupa bez przerwy funkcjonowały w świadomości narodowej wszystkich Polaków ${ }^{40}$. Dziewiętnasty wiek, do trwającej od ośmiu stuleci rzeczywistości dodał nowy element, kształtując ogólnopolskie wyobrażenia o Skałce. Skałka stała się miejscem wiecznego spoczynku zasłużonych dla Ojczyzny synów, zyskując miano Grobu Ojczyzny - Sepulchrum Patriae ${ }^{41}$. Tu zaczęto grzebać tych, którzy swą pracą tworzyli kulturę ojczystą, a w okresie zaborów pozwolili dzięki swym dziełom przetrwać narodowi. Początek urządzania uroczystych pogrzebów i tworzenia się Panteonu Narodowego na Skałce wiąże się z uroczystościami 400-lecia śmierci Jana Długosza, który od roku 1480 spoczywał w skałecznym kościele ${ }^{42}$ i otwarciem Krypty Zasłużonych w 1880 roku $^{43}$.

\footnotetext{
${ }^{36}$ J. U r b a n, Katedra na Wawelu (1795-1918), Kraków 2000, s. 225; M. R o ż e k, Wawel i Skatka..., s. 108.

${ }^{37}$ [Karol Suchodolski], Pamiqtka podniesienia relikwii Adama Mickiewicza z dodatkiem najpiękniejszych wyjątków z jego „Ksiag narodu polskiego i pielgrzymstwa polskiego", Kraków 1890, s. 3.

${ }^{38}$ Mickiewicz na Wawelu. Album pamiqtkowe zlożenia zwtok wieszcza w krypcie katedralnej, wyd. K. B a r t o s z e w i cz, Kraków 1890, s. 13.

${ }^{3 y}$ M. Swiątecka, Sprowadzenie zwłok... op. cit., s. 64, 74.

${ }^{40}$ M. R oże k, „Ara Patriae”. Dzieje grobu św. Stanisława w katedrze na Wawelu, „Analecta Cracoviensia" 11:1979, s. 452-460; F. Ziejka, Krakowscy pqtnicy, [w:] Klejnoty i sekrety Krakowa. Teksty z antropologii miasta, pod red. R. Goduli, Kraków 1994, s. 21-23; J. M o z g a, Historyczna rola sanktuarium św. Stanistawa w Krakowie na Skatce - wczoraj i dziś, „Studia Claromontana” 17:1997, s. 16-17; M. T o b i as z, Dziejowe znaczenie Skałki, „Tygodnik Powszechny” 8:1952, nr 7, s. 8.

${ }^{41}$ M. R o ż e k, Wawel i Skatka..., s. 217; tenże, Skatka jako Panteon Narodowy, „Peregrinus Cracoviensis", 14:2003, s. 122 .

${ }^{42}$ M. R o ż e k, Wawel i Skatka..., s. 229-231.

${ }^{43}$ L. Z a r e w i c z, Skatka z kościotem ś. ś Michata i Stanistawa w Krakowie, [w:] Kalendarz Krakowski Józefa Czecha na rok 1889, s. 81; K. Pieradzka, Zwiazki Długosza z Krakowem, Kraków 1975, s. 96-99.
} 
W czterechsetną rocznicę śmierci Jana Długosza, 19 maja 1880 roku odbyło się przeniesienie kości wybitnego historyka do nowego sarkofagu w krypcie i otwarcie w niej Grobów Zastużonych. Kości Długosza ${ }^{44}$ przełożono do metalowej trumienki, ozdobionej herbem Wieniawa, zalutowano, po czym przeniesiono do kościoła i postawiono na katafalku. O godzinie 10 rozpoczęła się uroczystość złożenia popiołów dziejopisa w nowej krypcie. Nabożeństwo żałobne celebrował bp Albin Dunajewski, a mowę pogrzebową wygłosił ks. kanonik Ignacy Polkowski. Po ceremoniach liturgicznych trumnę przenieśli na swych barkach z górnego kościoła do krypty, rektor i profesorowie Uniwersytetu Jagiellońskiego. Przy złożeniu trumny do sarkofagu przemówił bp Dunajewski, oddając cześć temu, który zapoczątkował Panteon Narodowy na Skałce, równocześnie powierzając w imieniu ojczyzny pieczę nad nim zakonowi paulinów ${ }^{45}$.

W niedługim czasie do Grobów Zasłużonych przybyły nowe trumny, a Skałka stała się kryptą dopełniającą wawelską nekropolię z grobami królewskimi i biskupimi $^{46}$. „Dnia 14 października tysiąc osiemset osiemdziesiątego pierwszego roku, o godzinie 8 przy odprawieniu Mszy św. i odśpiewaniu Salve Regina, pochowane zostały w kryptach Grobu Zastużonych na Skałce zwłoki śp. Wincentego Pola i Lucjana Siemieńskiego" ${ }^{\text {"47 }}$. Prochy obydwu poetów w obecności przeora paulinów o. Ambrożego Federowicza, zakonników, prof. Józefa Łepkowskiego oraz członków rodzin tych dwóch pisarzy przeniesiono z cmentarza Rakowickiego na Skałkę i złożono pod posadzką skałecznej krypty ${ }^{48}$.

W dniu 19 marca 1887 roku zmarł w Genewie znany powieściopisarz historyczny Józef Ignacy Kraszewski. Władze Krakowa i Lwowa postanowiły uczcić Kraszewskiego pogrzebem na Skałce ${ }^{49}$. Dnia 5 kwietnia, trumnę ze zwłokami pisarza przywieziono z Genewy. Szczątki zasłużonego męża powitał w imieniu władz miasta Krakowa prezydent Feliks Szlachtowski, po czym przewieziono trumnę karawanem do kościoła księży pijarów i złożono w krypcie pod tą świątynią. Dopiero18 kwietnia odbył się uroczysty pogrzeb. Rano, po Mszy św. odprawionej przez prałata Henryka Matzke, uformował się kondukt, który zgromadził profesorów Uniwersytetu Jagiellońskiego, członków Akademii Umiejętności, reprezentacje Lwowa, krakowską radę miejską, rodzinę pisarza oraz młodzież. Przed kościołem pijarów zmarłego pożegnał w imieniu Akademii prof. Józef Majer, po czym żałobny orszak ruszył ulicą św. Jana na Skałkę. Następnie trumnę wniesiono do prezbiterium kościoła Mariackiego. Tu Mszę św. celebrował bp Albin Dunajewski, a kaza-

\footnotetext{
${ }^{44}$ Archiwum 00. Paulinów na Skałce w Krakowie (dalej: APS) sygn. 292, Dokument stwierdzajacy kości Jana Dlugosza, s. 5.

${ }^{45}$ Pamiętnik pierwszego zjazdu historycznego polskiego imienia Jana Dhugosza odbytego w Krakowie w czterechsetnq rocznice jego śmierci, Kraków 1881, s. 16.

${ }^{46}$ Archiwum Państwowe w Krakowie (dalej: APKR), UR 61, Plan grobu na Skatce, s. 31.

${ }^{47}$ APS, sygn. 292, Opis pogrzebu Wincentego Pola i Lucjana Siemieniskiego, s. 11.

${ }^{48}$ L. Z a r e w i c z, Skalka z kościotem..., op. cit., s. 87-88.

49 Program obrzędu pogrzebowego ś.p. Józefa I. Kraszewskiego w Krakowie, Kraków 1887.
} 
nie wygłosił ks. Władysław Chotkowski ${ }^{50}$. W samo południe, przy dźwiękach hejnału z wieży mariackiej trumnę złożono na karawanie i kondukt wzdłuż szpaleru ludzi ruszył ul. Grodzka, Stradomiem, Krakowską i Skałeczną do kościoła paulinów. Orszakowi towarzyszył żałobny ton dzwonów ze wszystkich krakowskich kościołów z Zygmuntem na czele. Przy śpiewie hymnu Salve Regina złożono trumnę do Krypty ${ }^{51}$. Pogrzeb Kraszewskiego na Skałce był jednym z najbardziej przygotowanych pogrzebów w Krakowie. Jak pisała po latach Alina Świderska, w tym dniu „cały Kraków wyległ na ulice i sporo znalazło się przyjezdnych. Straż trzymała młodzież uniwersytecka i gimnazjalna (wszystkie szkoły naturalnie były zamknięte), dzień był, zdaje mi się, jakoś wczesnowiosenny, ale bardzo pogodny. Szczegółów już sobie nie przypominam, pozostało tylko ogólne wrażenie. Mimo niezmiernie licznego tłumu nie wyczuwało się takiej żądzy sensacji, jak na widowisku. Nie umiem tego dobrze określić, żeby nie popaść we frazeologię, słowem, było to właśnie owo „coś", cechujące pogrzeby krakowskie",52.

Pod koniec XIX wieku pogrzebano w skałecznym kościele dwóch znanych poetów: Teofila Lenartowicza i Adama Asnyka. Pierwszy zmarł we Florencji 3 lutego 1893 roku. Za udział w Wiośnie Ludów musiał opuścić kraj i pójść na dalekie szlaki emigracyjne. Osiadł we Florencji. Twórczość Lenartowicza przepojona była patriotyzmem, a tomiki jego poezji znane były $w$ całym $\mathrm{kraju}^{53}$. W niedzielę, 11 czerwca o godzinie 16 wagon kolejowy wiozący trumnę Lenartowicza z Florencji przybył do Krakowa na Dworzec Główny. Uroczysty akt wprowadzenia zwłok Lirnika Mazowieckiego do Krakowa odbył się tego samego dnia wieczorem. O godzinie 20 przybyli na plac kolejowy przy ul. Pawiej członkowie Komitetu Obywatelskiego, rada miasta z prezydentem Józefem Friedleinem, reprezentacja Lwowa, delegacja Towarzystwa Naukowego w Poznaniu, duchowieństwo świeckie i zakonne, rodzina Lenartowicza oraz wiele osób ze świata literackiego i artystycznego. Trumnę po wyjęciu $z$ wagonu złożono na przygotowanych specjalnie noszach i przykryto aksamitną zasłoną, na której położono 38 wieńców przywiezionych z Florencji i Wiednia ${ }^{54}$. Następnie Chór Towarzystwa Muzycznego odśpiewał Beati mortui, po czym kondukt pogrzebowy ruszył ul. Pawia, Basztową i Floriańską do kościoła Mariackiego. Pochód rozpoczynały drużyny Sokołów z całego kraju, a po nich postępował oddział ochotniczej straży pożarnej i duchowieństwo. Nosze z trumną poety-tułacza niosła na przemian na swoich barkach młodzież akademicka i grupy Sokołów. Za trumną postępowała rodzina zmarłego, reprezentacja Lwowa i Krakowa, różne deputacje i tysiące publiczności. „Powoli, majestatycznie, wśród chóral-

${ }^{50}$ T. Ch otk owski, Mowa powiedziana przy zwłokach śp. Józefa Kraszewskiego w Krakowie, w kościele archiprezbiterialnym N.P. Marii 18 kwietria 1887, Kraków 1887.

${ }^{51}$ L. Z a re w i c z, Skatka z kościołem..., op. cit., s. 88; Pogrzeb J. I. Kraszewskiego, [w:] Kalendarz Krakowski Józefa Czecha na rok 1888, s. 146.

${ }^{52}$ A. S w i de r s k a, Trwa, choć przeminęło, [w:] Kopiec wspomnień, Kraków 1959, s. 175-176.

${ }^{53}$ Kalendarz Krakowski Józefa Czecha na rok 1894, s. 139-140.

${ }^{54}$ Zwtoki Teofila Lenartowicza w Wiedniu, ,Kurier Polski” 5:1893, nr 159, s. 2. 
nych śpiewów kościelnych i odgłosu dzwonów posuwał się kondukt, ulicami oświetlonymi gazowymi pochodniami, ozdobionymi choragwiami o barwach narodowych"55. Wieczorem około godziny 21 trumnę ze zwłokami Lenartowicza wniesiono do kościoła Mariackiego i ustawiono na ozdobnym katafalku w prezbiterium. Pogrzeb wyznaczono na 12 czerwca. Tego dnia od wczesnego rana na ulicach panował wielki ruch. Całe miasto udekorowano, a z domów na ulicach przez które przechodzić miał orszak powiewały choragwie o barwach narodowych. O godzinie 9 kard. Albin Dunajewski w asyście licznego duchowieństwa odprawił Mszę św. żałobna, podczas której chóry pod batutą Wiktora Barabasza odśpiewały Requiem Mozarta, a o. Czesław Bogdalski, bernardyn wygłosił mowę pogrzebową ${ }^{56}$. Po Mszy św. i pokropieniu zwłok przez kardynała, pół godziny przed $12 \mathrm{w}$ południe, przy biciu dzwonów wyruszył pochód z kościoła Najświętszej Maryi Panny na Skałkę. Na jego czele szli ubodzy starcy z Towarzystwa Dobroczynności ze sztandarami, chłopcy z Zakładu św. Józefa, kapela Harmonii krakowskiej, deputacje Sokołów z całego kraju oraz dzieci krakowskie. Dalej postępowała młodzież szkół średnich, deputacje włościan w odświętnych strojach $\mathrm{z}$ wieńcami oraz reprezentacje różnych korporacji i stowarzyszeń. Długi, podwójny szereg duchowieństwa świeckiego i klasztornego wyprzedzał zwłoki Lirnika Mazowieckiego, niesione przez Sokołów. Za zwłokami postępowała rodzina poety, przedstawiciele miast stołecznych Krakowa i Lwowa, Uniwersytetów Jagiellońskiego i Lwowskiego i Akademii Umiejętności. Przy śpiewie Boże coś Polskę i $Z$ dymem pożarów, trumnę wnieśli do Krypty' członkowie rad miejskich Lwowa i Krakowa w obecności prezydentów obydwu miast, po czym spuszczono ją do grobu ${ }^{57}$.

Na początku sierpnia 1897 roku Kraków obiegła smutna wiadomość. Dnia 2 sierpnia zmarł Adam Asnyk. Rada miejska jako miejsce wiecznego spoczynku największego polskiego poety drugiej połowy XIX stulecia zaproponowała Skałkę. Termin uroczystości pogrzebowych wyznaczono na dzień 6 sierpnia $^{58}$. Do tego dnia zwłoki wystawione były w domu zmarłego przy ul. Łobzowskiej. Dnia 6 sierpnia, o godzinie 16, po mowie wygłoszonej przez prezydenta Józefa Friedleina wyruszył żałobny kondukt wiodący ul. Łobzowską, Placem Szczepańskim, Rynkiem Głównym, Grodzką na Skałkę. W uroczystości wzięli udział przedstawiciele Uniwersytetu Jagiellońskiego, Akademii Umiejętności, Sejmu Krajowego, Lwowa, cechy krakowskie, Towarzystwo Strzeleckie, kongregacja kupiecka. Wie-

\footnotetext{
${ }^{55}$ [Antoni Kleczkowski], Hołd lirnikowi mazowieckiemu Teofilowi Lenartowiczowi zlożony przez rodaków w Krakowie 12 czerwca 1893 r., Kraków 1893, s. 64.

${ }^{56} \mathrm{Cz}$. B og d a $1 \mathrm{~s} \mathrm{k} \mathrm{i,} \mathrm{Mowa} \mathrm{przy} \mathrm{uroczystym} \mathrm{przeniesieniu} \mathrm{zwtok} \mathrm{śp.} \mathrm{Teofila} \mathrm{Lenartowicza} \mathrm{do} \mathrm{Grobu}$ Zastużonych na Skatce powiedziana w czasie nabożeństwa w kościele Mariackim dnia 12 czerwca 1893 r., Kraków 1893.

${ }^{57}$ [Antoni Kleczkowski], Hotd lirnikowi mazowieckiemu..., op. cit., s. 65-67, 82-84, 99-106; Kalendarz Krakowski Józefa Czecha na rok 1894, s. 140-141; Ku czci Lenartowicza, „Kurier Polski” 5:1893, nr 159 , s. 2.

${ }^{58}$ Program obrzędu pogrzebowego ś.p. Adama Asnyka w' Krakowie w dniu 6 sierpnia 1897, Kraków 1897.
} 
czorem, o godzinie 19 przy śpiewie Salve Regina złożono trumnę w Krypcie Zastużonych ${ }^{59}$.

W Grobach Zastużonych na Skałce obok pisarzy i poetów przeznaczono także miejsce dla malarzy. Dnia 23 sierpnia 1902 roku zmarł Henryk Siemiradzki, malarz - twórca Pochodni Nerona. Pochowano go na warszawskich Powązkach, ale tuż po pogrzebie rada miasta Krakowa zwróciła się do rodziny zmarłego z prośbą o zgodę na pochowanie zwłok Siemiradzkiego na Skałce. Dnia 24 września 1903 roku doczesne szczątki malarza przewieziono z Warszawy do Krakowa. Właściwy pogrzeb odbył się 26 września. Kamienice i budynki w mieście przyozdobiono żałobnie, wieszając flagi o barwach narodowych spowite kirem. Ceremonia pogrzebowa rozpoczęła się Mszą św. w kościele Mariackim, na którą przybyła rodzina zmarłego, przedstawiciele rady miejskiej, profesorowie Uniwersytetu Jagiellońskiego i członkowie Akademii Umiejętności. Po nabożeństwie i przemówieniach, trumnę umieszczono w rydwanie, a kiedy zabrzmiały dzwony, a orkiestra zagrała marsza żałobnego Fryderyka Chopina, orszak pogrzebowy ruszył na Skałkę. Na czele konduktu szła miejska straż ogniowa, dalej postępowali Sokoli, urzędnicy miejscy, rada miasta Podgórza, włościanie i cechy. Za trumną podążała rodzina zmarłego, posłowie krakowscy, rada miejska, delegaci Lwowa, przedstawiciele Wydziału Krajowego, profesorowie Uniwersytetu oraz uczniowie szkół średnich. W kościele na Skałce odmówiono modlitwy, po czym trumna spoczęła w Grobach Zastużonych ${ }^{60}$.

Wkrótce pogrzebano w Panteonie Narodowym na Skałce Stanisława Wyspiańskiego, zmarłego 28 listopada 1907 roku $^{61}$. Wieść o śmierci artysty wywarła w całym Krakowie wstrząsające wrażenie. Wywieszono czarne choragwie na gmachu magistratu, Akademii Sztuk Pięknych, Towarzystwie Sztuk Pięknych i na Teatrze Miejskim. Kraków przygotowywał się do uroczystości pogrzebowej, która zgodnie z ostatnią wola zmarłego miała odbyć się bez mów. Trumnę ze zwłokami złożonymi w skromnej, metalowej trumnie, przeniesiono 29 listopada do krypty kościoła księży pijarów. Właściwy pogrzeb odbył się 2 grudnia 1907 roku. Przy ładnej, lecz mroźnej pogodzie o godzinie 10, malarze - koledzy zmarłego, przenieśli trumnę na swych barkach z podziemnej krypty kościoła pijarów do kościoła Mariackiego. Na Rynku Głównym zebrały się tłumy, w tym krakowscy studenci, zakopiańscy górale i podkrakowscy włościanie. W kościele Mariackim złożono trumnę na katafalku ustawionym przed ołtarzem Wita Stwosza. Otoczyły go cechowe poczty sztandarowe i czeladź rzeźnicza $\mathrm{z}$ historycznymi nożami osłoniętymi czarną krepą. Mszę św. żałobną odprawił ks. Krzemieński w asyście duchowień-

${ }^{59}$ Kalendarz Krakowski Józefa Czecha na rok 1898, s. 139-142; M. R oże k, Wawel i Skatka..., s. $242-243$.

${ }^{60} \mathrm{~J}$. D u ż y k, Siemiradzki, Warszawa 1986, s. 537-539; M. R o ż e k, Panteon narodowy na Skatce..., s. 91-93; M. R o ż e k, Wawel i Skatka..., s. 243-245.

${ }^{61}$ M. R o m a n ow s k a, Pogrzeb Stanistawa Wyspiańskiego, „Rocznik Krakowski” 54:1988, s. 211-216; K. Z b i j e w sk a, Mqż znakomity, „Dziennik Polski” 58:2002, nr 278, s. 33; K. Z b i je w sk a, Krakowskim szlakiem Stanisława Wyspiańskiego, Warszawa 1986, s. 42-44. 
stwa, a krakowski chór akademicki wykonał Hymn do Ducha Świętego autorstwa Stanisława Wyspiańskiego. Po nabożeństwie trumnę złożono na czarnym, wysokim rydwanie zaprzężonym w trzy pary koni. W samo południe, kiedy zabrzmiał hejnał z wieży mariackiej wyruszył żałobny orszak. Obszedł Rynek Główny, a następnie skierował się ul. Grodzką ku Skałce. Niezwykłe wrażenie wywołał pochód młodzieży akademickiej z płonącymi pochodniami, z których unoszące się dymy okrywały ulice kirem żałoby. Wieńce wieziono na rydwanie pogrzebowym, zaprzężonym w parę koni, obok zaś postępowali artyści malarze. Trumnę ze zwłokami poety wiózł sześciokonny rydwan, za którym szła rodzina zmarłego, przyjaciele, profesorowie Akademii Sztuk Pięknych, Uniwersytetu Jagiellońskiego i Uniwersytetu Jana Kazimierza, marszałek krajowy, rada miejska, członkowie Akademii Umiejętności, delegaci Podgórza oraz urzędnicy miejscy. Wzdluż trasy konduktu płonęły gazowe latarnie, przewiązane żałobnymi kokardami. Tysiące krakowian żegnało wybitnego artystę. Na czas pogrzebu zamarło życie w mieście. Przed bramą klasztoru paulinów studenci Akademii Sztuk Pięknych zdjęli trumnę i ponieśli do Krypty. Tu oczekiwał przeor klasztoru o. Ambroży Federowicz razem z klerem. Zgodnie z wolą Stanisława Wyspiańskiego nie padło żadne słowo. Przy śpiewie chóru akademickiego wniesiono trumnę do Krypty i ustawiono naprzeciw sarkofagu Adama Asnyka. Ceremonię pogrzebową zakończyło odśpiewanie Salve Regina i oracje liturgiczne.

Pełne splendoru były pogrzeby nie tylko na Wawelu i Skałce, ale także na cmentarzu Rakowickim. Tłumnie odprowadzano na Rakowice polityków, artystów, literatów i uczonych oraz wszystkich tych, którzy swym życiem i pracą świadczyli, że Jeszcze Polska nie zginęta, a nadzieja na jej odrodzenie nie jest składana razem ze zmarłym do grobu lecz zawsze żyje i podtrzymuje Polaków na duchu. Większość konduktów pogrzebowych kierowała się na cmentarz Rakowicki, który w tym czasie stał się tradycyjnym miejscem pochówków patriotycznych, a tym samym ważnym punktem narodowej przestrzeni, drugim pod względem ważności po Wawelu. Kwatera R, określona jako Polonia stała się tradycyjnie miejscem pochówku i czci ofiar przemocy zaborców ${ }^{62}$. Na pogrzebach znanych ludzi gromadziło się kilka tysięcy osób, a w kondukcie pogrzebowym szły cechy z choragwiami, Towarzystwo Strzeleckie i różne korporacje. Pogrzeby generałów powstania listopadowego z 1830 roku, Józefa Chłopickiego i Jana Skrzyneckiego były okazją do patriotycznych manifestacji podobnych do wzorca, który dały wielkie pogrzeby doby Wolnego Miasta Krakowa. W 1860 roku kilkanaście tysięcy osób zgromadził pogrzeb generała Jana Skrzyneckiego. Trumnę do kościoła Najświętszej Maryi Panny nieśli towarzysze broni na zmianę ze studentami, a sznury całunu trzymali generałowie. W czasie przejścia konduktu z kościoła Mariackiego na cmentarz Rakowiecki biły dzwony we wszystkich kościołach krakowskich z Zygmuntem na

${ }^{62} \mathrm{R}$. K a n t or, Krakowskie pogrzeby - budowanie przestrzeni narodowej. Z dziejów obrzędowości patriotycznej w okresie zaborów, „Rocznik Muzeum Etnograficznego” 11:1994, s. 70. 
czele. W 1862 roku w wieku 90 lat zmarł Marcin Tarnowski, ostatni żołnierz insurekcji kościuszkowskiej. Jego trumnę nieśli polscy oficerowie, a uczestnicy ceremonii pogrzebowej, którzy nie pomieścili się w kościele Mariackim zalegli cały Rynek Główny. Po egzekwiach uroczysty kondukt, któremu przewodniczył kanonik krakowskiej kapituły katedralnej Scipio del Campo wyruszył na cmentarz. Trumnę nieśli na zmianę krewni zmarłego, zamożni obywatele, oficerowie i młodzież akademicka, a dalej postępowały cechy z choragwiami. Na uczestnikach szczególne wrażenie wywarła „zmiana niosących trumnę na kamieniu Kościuszki, bo przecież chowano ostatniego z żołnierzy Naczelnika"63. Po pogrzebie rozszarpano całun na pamiątkę tych wspaniałych uroczystości. Uroczysty charakter miał pogrzeb ofiar bombardowania Krakowa w 1848 roku. Zginęły wtedy 32 osoby, zarówno chrześcijanie, jak i Żydzi, dorośli i dzieci. Pogrzeb odbył się 29 kwietnia. Po odprawieniu nabożeństwa w kościele Mariackim, złożono do grobu 17 trumien niesionych na barkach osób różnych stanów ${ }^{64}$. Jak wspominała Aniela Louisówna „okropny był to widok - wszyscy czarno ubrani, kobiety niosły trumny. 17 trumien było - wszystkie wieńcami ubrane i na każdej krakuska z kokardą"65.

Obyczaj patriotycznych ceremonii pogrzebowych wszedł również w czasie ogólnego, patriotycznego uniesienia do zwyczajów pogrzebowych osób cywilnych, nie związanych z walką narodową, a jedynie poprzez użycie symboli świadczących o przynależności narodowej i patriotyzmie ${ }^{66}$. „W tej epoce - pisze Maria Estreicherówna - kiedy uczucia patriotyczne rozżarzone były do białości, lubowano się w efektach, które dla nas wydawałyby się zbyt teatralne, a nie raziły wobec ogólnej egzaltacji. Przykładem na to może być pogrzeb panny Kwiatkowskiej w roku 1861, która kazała się pochować w białej aksamitnej trumnie, białej, ciężkiej materialnej sukni i zanieść do grobu przez sześciu młodzieńców w strojach narodowych" ${ }^{167}$. W 1863 roku odbył się szereg pogrzebowych manifestacji, kiedy chowano uczestników powstania styczniowego, a zwłaszcza krakowską młodzież poległą w walkach lub zmarłą od ran w czasie wyprawy na Miechów 17 lutego 1863 roku. Polski oddział został wtedy rozbity i poniósł dotkliwą klęskę. Zginęło kilkaset młodych ludzi. Na wiadomość o wydarzeniu miasto okryło się żałobą, a na murach kościolów pojawiły się zawiadomienia o nabożeństwach za poległych. Na cmentarz odprowadzały poległych wszystkie bractwa i cechy, liczne duchowieństwo i potężne tłumy ludzi. Pogrzeby przybrały charakter potężnych, pełnych spokoju demonstracji narodowych, które na Austriakach wywierały duże wrażenia ${ }^{68}$. Nader podniosły

\footnotetext{
${ }^{63}$ M. E stre i c h e ró w n a, Życie towarzyskie i obyczajowe Krakowa w latach 1848-1863, Kraków 1968 , s. 214.

${ }^{64}$ W. K o p f f, Wspomnienia z ostatnich lat Rzeczypospolitej Krakowskiej, wyd. S. Estreicher, Kraków 1906, s. 121. (Biblioteka Krakowska nr 31)

${ }^{65}$ Pamiętniki krakowskiej rodziny Louisów (1831-1869), oprac. J. Zathey, Kraków 1962, s. 177-178.

${ }^{66}$ R. K a n t o r, Krakowskie pogrzeby..., s. 70.

${ }^{67} \mathrm{M}$. Es s r e i c h e ró w n a, Życie towarzyskie i obyczajowe..., op. cit., s. 214.

${ }^{68}$ W. To k a r z, Kraków w poczqtkach powstania styczniowego i wyprawa na Miechów, t. 2, Kraków 1914, s. 221-222.
} 
i manifestacyjny charakter miał w sierpniu 1863 roku, pogrzeb ofiar wybuchu w tajnej prochowni przy ul. Szewskiej. Zginęło wtedy pięć młodych osób (4 dziewczyny i 1 chłopiec) Ambroży Grabowski pisał, że był to „najuroczystszy pogrzeb w ciagu 66 lat jego pobytu w Krakowie. Floriańska, Szpitalna, Plantacje, Lubicz, ulica do cmentarza wiodąca [...] była to jedna masa kilkunastu tysięcy ludzi, a na cmentarz nie można się było docisnąć. Młodzież niosła trumny dziewic okryte kwiatami" ${ }^{\prime \prime}$.

Równie uroczyste pogrzeby, połączone z okolicznościowymi przemówieniami, nabożeństwami i wielotysięcznymi pochodami, organizowane według przemyślanego ceremoniału, urządzały władze Krakowa zmarłym prezydentom miasta. Tak właśnie chowano Józefa Dietla $(1878)^{70}$, Mikołaja Zyblikiewicza $(1887)^{71}, \mathrm{Fe}$ liksa Szlachtowskiego (1896), Ferdynanda Weigla (1901). Tłumy odprowadzały na Rakowice wybitnych artystów: Jana Matejke $(1893)^{72}$ i Helenę Modrzejewską (1909).

Liczne krakowskie pogrzeby składały się na to, co nazywamy budowaniem narodowej przestrzeni ${ }^{73}$. Bogaty, precyzyjnie zrealizowany program uroczystości pogrzebowych, dostarczał głębokich narodowych przeżyć wszystkim warstwom społecznym, na wszystkich poziomach narodowej świadomości. Specyficzna atmosfera, w której odbywały się pochówki w podwawelskim grodzie, działały na zmysły i pobudzały do refleksji. Pogrzeby, mające w większości charakter manifestacji patriotycznych, zaspokajały zarówno uczucia ściśle patriotyczne i religijne jak $\mathrm{i}$ - nader ludzkie - potrzeby uczestniczenia w ostatniej drodze zmarłego. W wielkim spektaklu, jakiego cząstką obok innych uroczystości narodowo-kościelnych były krakowskie pogrzeby, na zwykła, przeżywaną po ludzku śmieré i żal po zmarłym nie było w istocie miejsca. Indywidualna śmierć, przeciętnego obywatela krakowskiego został zepchnięta na dalszy plan przez ideę życia narodu i była przeżywana jedynie w sercach najbliższych. Wybitny zmarły wódz, twórca, patriota, bojownik o wolność stawał się cząstką życia narodu. W ten sposób nastąpiło pewnego rodzaju oswojenie śmierci i zawarcie jej w narodowym obrzędzie.

Sławne pogrzeby w XIX-wiecznym Krakowie i krakowska pompa funebris, dodawały miastu powagi, wysuwając go na czoło miast dawnej Rzeczypospolitej. Tadeusz Boy-Żeleński nieświadomie krytykując krakowskie pogrzeby trafił w sedno pisząc: „Wszystko w tym mieście było paradoksalne. Śmierć stawała się ele-

${ }^{69}$ M. E s t r e i c h e r 0 w n a, Życie towarzyskie i obyczajowe..., op. cit., s. 214.
${ }^{70}$ Program obrzedu pogrzebowego s.p. dr Józefa Dietla b. prezydenta miasta Krakowa, Kraków 1878.
${ }^{73}$ Program obrzedu pogrzebowego ś.p. Mikotaja Zyblikiewicza bytego marszałka krajowego, Kraków
W. C h o t k o w s k i, Mowa żałobna powiedziana na pogrzebie ś.p. Mikołaja Zyblikiewicza, w Kra1887; W. C h o t k o w s k i, Mowa żałobna powiedziana na pogrzebie s.p. Mikołaja Zyblikiewicza, w Kra-
kowie w kościele archiprezbiterialnym N. P. Maryi dnia 23 maja $1887 \mathrm{r}$., Kraków 1887.

${ }^{72}$ M. P r ze m e c k a - Z i e l ińs k a, Krakowskim szlakiem Jana Matejki, Kraków 2003, s. 127-129; A. St e rn chus s, Dom Jana Matejki, Kraków 1898, s. 10. (Biblioteka Krakowska nr 9); Artystę pochowano w grobie rodzinnym, gdyż nie życzył sobie być pochowanym na Skałce. Zob. W. D a n ek, Matejko i Kraszewski. Dwie koncepcje dziejów Polski, Wrocław 1969, s. 11.

${ }^{73}$ R. K a n t o r, Krakowskie pogrzeby..., s. 72-74. 
mentem życia. Ważnym faktem krakowskiej kroniki były pogrzeby. Mając i Wawel, i Skałkę, Kraków stał się wielkim domem przedpogrzebowym całej Polski. Od niezapomnianego pogrzebu Mickiewicza iluż dostojnych umarłych ciagnęło przez te ulice: Kraszewski, Lenartowicz, Matejko, Asnyk, Wyspiański" "'4. Prawdziwe zrozumienie dla roli Krakowa jako nekroplu polskiego wyraził w 1869 roku Michał Bałucki pisząc, że „każdy naród i każde miasto ma swoje posłannictwo dziejowe, opatrzność i poeci skazali Kraków na miasto grobów, na urnę pamiątek i popiołów"75. Kraków w XIX wieku stał się „matecznikiem Polski, do którego przybywają na starość wielkie 1wy, orły i niedźwiedzie (choć czasem i lamparty), by tu złożyć swe kości" ${ }^{\text {"76 }}$. To właśnie ich pogrzeby stawały się patriotycznymi manifestacjami, a ich pompa i decorum dziedzictwem tradycji pogrzebów królewskich.

\section{Famous Funerals in $19^{\text {th }}$ Century Cracow}

Cracow, the old capital of Polish Kingdom, has always performed a particular role in the Polish history and culture. In the nineteenth century, particulary in the period of galician autonomy 1860-1914, Cracow became the spiritual capital of Poland for generations of Poles who lived in the partitioned country, which was ruled by the three foreign powers together. About this phenomenon decided not only the autonomy but also the old tradition and the symbolism of this town. In the 19 th century and before the First World War, Cracow was the most influential centre of the Polish national life.

In this time Crakow's citizens decided to continue the old tradition of the royal burial. Since there were no longer any Polish monarchs, they resolved that the remains of the greatest national heroes, of writers and artists be buried on the Wawel Cathedral in the cemetery Rakowice and later in the Church of Paulinites fathers "on the rock". Famous funerals in 19 th century Cracow, of which the best known were those of prince Joseph Poniatowski in 1817, general Thaddeus Kosciusko in 1818, king Casmir the Great in 1869 and of poet Adam Mickiewicz in 1890 alluded to royal ceremonies from the time of Polish independence. These funerals have been one of the main elements in patriotic and religious ceremonies and important part of the nation's patriotic educations.

${ }^{74}$ T. B o y - Ż e l eń sk i, O Krakowie, oprac. H. M a rk i e w i c z, Kraków 1973, s. 122.

${ }^{75}$ K. G r o dz i s k a - Oźó g, Cmentarz Rakowicki w Krakowie, Kraków 1987², s. 89.

${ }^{76} \mathrm{~S}$. Es t re i c he r, Znaczenie Krakowa dla życia narodowego polskiego $w$ ciagu $w$. XIX, [w:] Kraków w XIX wieku, t. 1, Kraków 1932, s. 17. (Biblioteka Krakowska nr 72) 


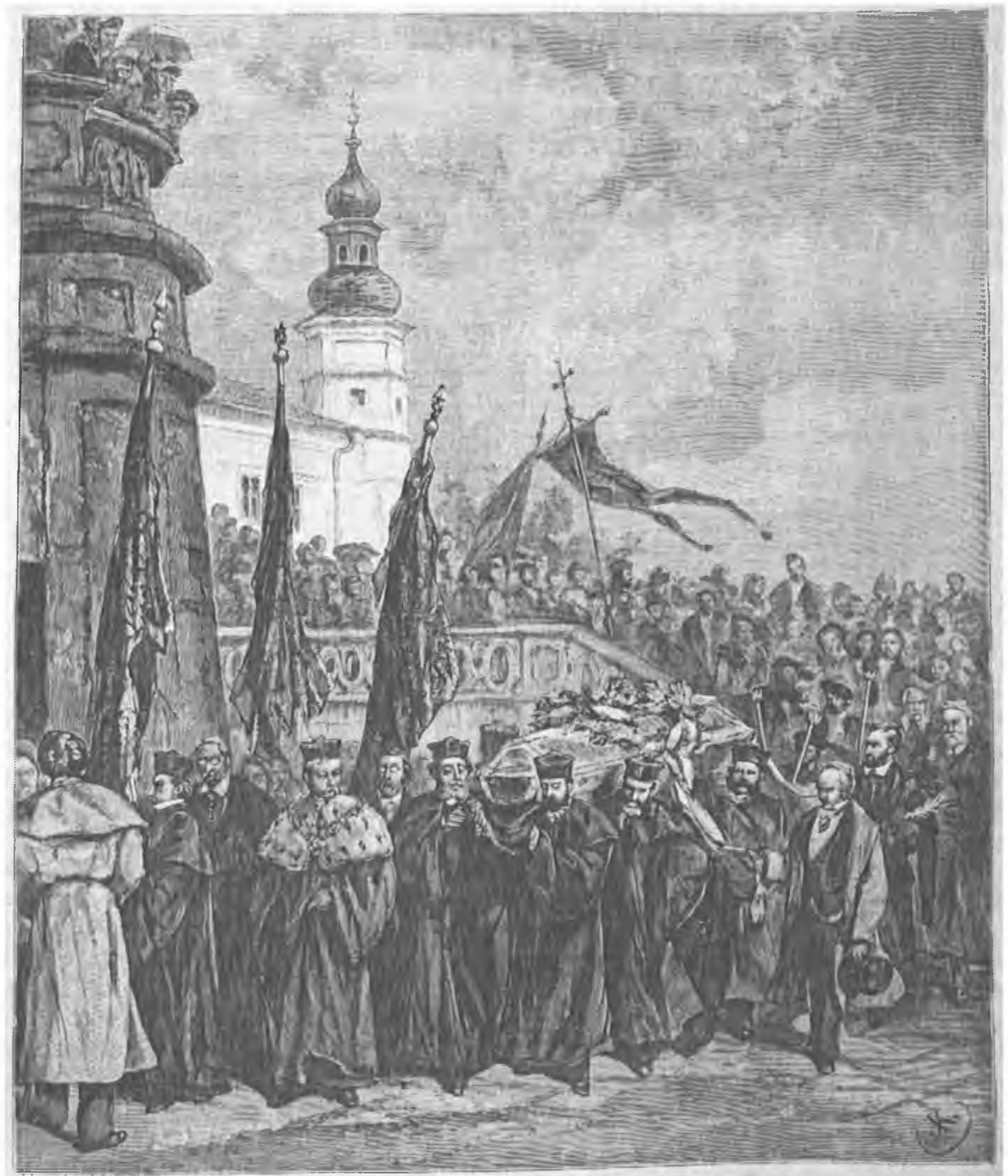

Przeniesienie kości Jana Długosza z kościoła do krypty na Skałce, rys. Juliusz Kossak, wg „Tygodnik Ilustrowany” ser. III, 9:1880, nr 233, s. 377 


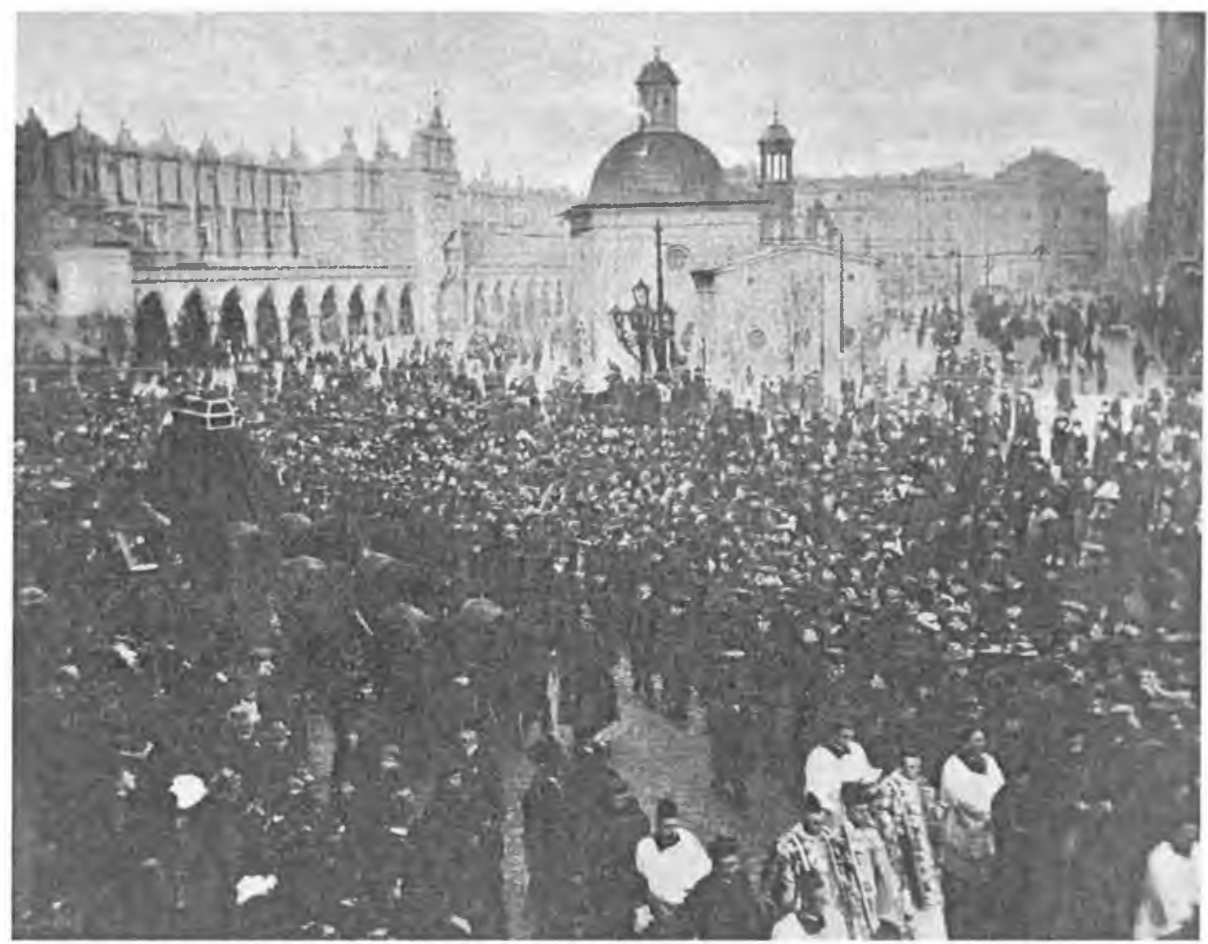

Korowód pogrzebowy Stanisława Wyspiańskiego na Rynku Głównym w Krakowie, wg „Tygodnik Ilustrowany” 1907, nr 49, s. 1004. 


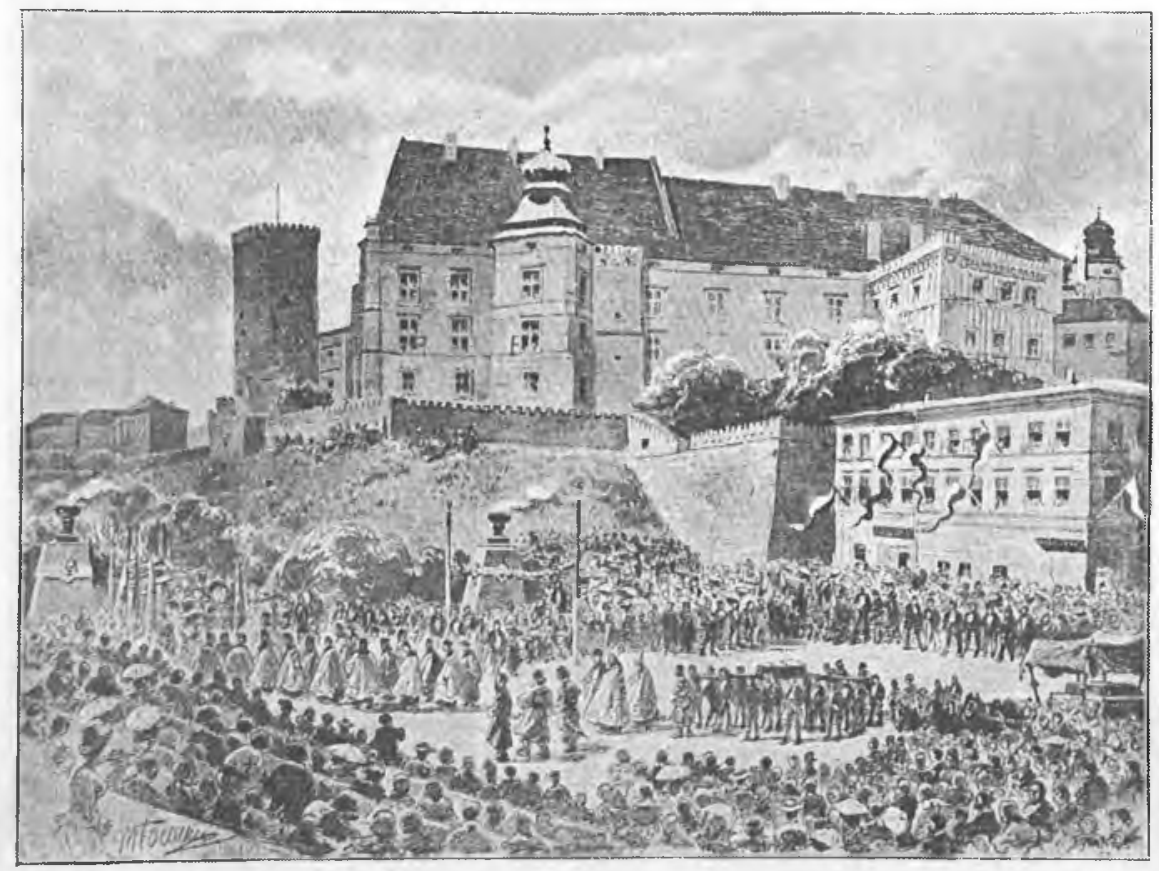

Orszak pogrzebowy Adama Mickiewicza pod Wawelem, rys. Michał Pociecha, wg ,Swiat" 3:1890, nr 14, s. 345. 